\title{
DAMPAK PENGGUNAAN TEKNOLOGI INFORMASI DAN KOMUNIKASI TERHADAP PERILAKU SOSIAL SISWA DI MAN 2 KUNINGAN
}

\author{
Siti Khodijah $^{1}$, Yeti Nurizzati ${ }^{2}$ \\ IAIN Syekh Nurjati Cirebon ${ }^{1,2}$ \\ khodijahsiti0231@gmail.com; yeti@syekhnurjati.ac.id
}

\begin{abstract}
Abstrak
Berdasarkan studi pendahuluan yang penulis lakukan di MAN 2 Kuningan yang terletak di Jl. Siliwangi Desa Ciawigebang Kecamatan Ciawigebang Kabupaten Kuningan masalah yang teridentifikasi diantaranya penggunaan teknologi informasi dan komunikasi khususnya handphone smartphone di kalangan siswa kelas XII IPS yang dipergunakan tidak menyesuaikan tempat dan waktu penggunaanya. Penggunaan handphone di lingkungan sekolah berimbas kepada perubahan perilaku sosial siswa kepada guru maupun siswa lainnya. Penelitian ini bertujuan untuk mengetahui penggunaan teknologi informasi dan komunikasi siswa kelas XII IPS, mendeskripsikan perilaku sosial siswa terhadap guru, siswa dengan siswa di lingkungan sekolah, dan menganalisis dampak dari penggunaan teknologi informasi dan komunikasi khususnya handphone smartphone terhadap perilaku sosial siswa di MAN 2 Kuningan. Penelitian menggunakan metode deskriptif kualitatif dengan teknik pengumpulan data menggunakan observasi, wawancara mendalam, dokumentasi, dan triangulasi. Teknik analisis data melalui tiga tahap yaitu reduksi data, penyajian data, dan verifikasi data. Dengan subjek penelitian adalah kepala sekolah, guru, dan beberapa siswa kelas XII IPS. Hasil penelitian menunjukan bahwa 1) penggunaan teknologi informasi dan komunikasi khususnya handphone smartphone digunakan di waktu dan tempat yang kurang tepat 2) terjadi perubahan perilaku sosial siswa ketika mereka memainkan handphone smartphone, interaksi sosial diantara siswa menjadi terganggu. 3) dampak negatif dari penggunaan teknologi informasi dan komunikasi handphone smartphone di lingkungan sekolah yaitu: siswa tidak fokus saat belajar, siswa menjadi individualis, dan menghiraukan lingkungan sekitar mereka. Sedangkan dampak positifnya yaitu: membantu siswa mencari bahan materi tambahan, membantu siswa mengerjakan tugas sekolah, dipergunakan siswa untuk berwirausaha dengan berjualan online melalui handphone smartphone.
\end{abstract}

\section{Kata kunci: teknologi informasi dan komunikasi, handphone smartphone, perilaku social}

\author{
Abstract \\ Based on the preliminary study that the author did in MAN 2 Kuningan located on \\ Jl. Siliwangi Ciawigebang Village, Ciawigebang District, Kuningan District, the \\ Jurnal Edueksos Volume VII No 2, Desember 2018


problems identified include the use of information and communication technology, especially smartphone phones among students of class XII IPS that are not used to adjust the place and time of use. The use of mobile phones in the school environment has an impact on students' social behavior changes to teachers and other students. This study aims to determine the use of information and communication technology in class XII IPS, describing students 'social behavior towards teachers, students with students in the school environment, and analyzing the impact of the use of information technology and communication, especially smartphone phones on students' social behavior in MAN 2 Kuningan. The study used descriptive qualitative method with data collection techniques using observation, in-depth interviews, documentation, and triangulation. Data analysis techniques through three stages, namely data reduction, data presentation, and data verification. With the subject of the study were the principal, teacher, and some students of XII social studies. The results showed that 1) the use of information technology and communication, especially smartphone phones were used at the wrong time and place 2) there was a change in students' social behavior when they played smartphone phones, social interaction between students became disrupted. 3) the negative impact of the use of smartphone mobile information and communication technology in the school environment, namely: students do not focus on learning, students become individualistic, and ignore the environment around them. While the positive impact is: helping students find additional material, helping students work on school assignments, using students to entrepreneurship by selling online through smartphone phones.

Keywords: information and communication technology, smartphone mobile, social behavior

\section{A. PENDAHULUAN}

\section{Latar Belakang}

Undang-undang Republik Indonesia Nomor 11 Tahun 2008 tentang Informasi dan Transaksi Elektronik. Pada BAB II Asas dan Tujuan pasal 3, Pemanfaatan teknologi informasi dan komunikasi dilaksanakan berdasarkan asas kepastian hukum, manfaat, kehati-hatian, iktikad baik, dan kebebasan memilih teknologi atau netral teknologi.

Perkembangan ilmu pengetahuan dan teknologi telah mendorong kemajuan di semua bidang kehidupan, termasuk kemajuan dalam bidang teknologi informasi. Hal ini telah membuka kesempatan bagi umat manusia untuk mengakses semua informasi global yang mengakibatkan terjadinya gejala dunia tanpa batas (bordless world). Peristiwa terjadi disalah satu belahan dunia dengan mudah dapat diketahui oleh masyarakat dibelahan dunia lainnya. 
Internet saat ini banyak berperan dalam kehidupan manusia dan kemajuan teknologi saat ini mendukung pula peran tersebut sehingga teknologi komputer dan internet dimanfaatkan pada berbagai bidang seperti misalnya mengerjakan tugas sekolah, belajar, mengatur keuangan keluarga, mndengarkan musik, menonton video, dan menikmati permainan (Maryono dan Istiana, 2007:33).

Perkembangan anak yang dimaksud disini adalah perubahan. Melihat perkembangan teknologi yang begitu cepat, mudah dijangkau oleh semua kalangan terlebih khusus di kalangan pelajar yang memberikan dampak tingkah laku sosial di lingukngan sekolah. Karena bisa kita lihat saat ini banyak pelajar yang sudah pandai mempergunakan alat informasi dan komunikas handphone smartphone baik untuk sekedar berkomunikasi, mencari tugas, games, hingga melihat situs-situs yang tidak seharusnya dilihat seperti, situs kekerasa, situs pornografi dll. Ini membuktikan bahwa pengaruh dari perkembangan teknologi informasi dan komunikasi memberikan dampak yang sangat mengkhawatirkan karena sedikit demi sedikit perkembangan teknologi ini memberikan pengaruh terhadap perilaku sosial siswa, melunturkan nilai-nilai kebudayaan.

Remaja tampak belum mampu memilah aktivitas internet yang bermanfaat dan cenderung mudah terpengaruh oleh lingkungan sosial tanpa mempertimbangkan terlebih dulu efek positif atau negatif yang akan diterima saat melakukan aktivitas internet tertentu. Oleh karena itu, tidak mengherankan jika selama ini perilaku online remaja selalu dijadikan sorotan utama untuk dikaji, baik oleh pihak pemerintah maupun lingkungan akademis.

MAN 2 Kuningan salah satu tempat yang sudah terkena dampak dari perkembangan teknologi informasi dan komunikasi khususnya (Handphone Smartphone). Siswa di MAN 2 Kuningan sudah dengan mudah mengakses berbagai macam alat Informasi dan Komunikasi, salah satu contohnya yaitu handphone (HP). Hanphone yang digunakan oleh siswa bukan hanya sekedar untuk berkomunikasi, mengerjakan tugas-tugas sekolah, untuk mencari referensi materi pelajaran, alat untuk transaksi jual beli, mendengarkan 
musik, namun tidak jarang handphone smartphone tersebut disalahgunakan oleh sebagian para siswa untuk melihat situs-situs yang tidak selayaknya dilihat oleh para siswa atau dikalangan pelajar diantaranya: situs kekerasan, situs pornografi, games online.

Adanya penggunaan handphone smartphone (HP) di lingkungan sekolah dapat mempermudah untuk mencari tambahan materi dan membantu siswa untuk mencari sumber-sumber materi yang bisa di dapatkan di situs internet, mempermudah siswa mengerjakan tugas. Namun selain itu adanya penggunaan handphone smartphone (HP) di lingkungan sekolah juga dapat mempengaruhi perilaku sosial siswa, saat siswa mempergunakan handphone smartphone (HP) tersebut tidak sesuai waktu dan tempat yang semestinya. Ketika handphone smartphone dipergunakan di dalam kelas ketika pembelajaran sedang berlangsung ini akan mengganggu proses belajar siswa, dan tidak jarang siswa tidak merespon apa yang disampaikan oleh guru. Ketika dipergunakan di jam istirahat ini juga berdampak pada ineraksi siswa dengan siswa lainnya, yang menjadikan siswa tersebut menjadi indivual yang tidak memperdulikan lingkungan sekitarnya karena terlalu fokus dengan handphone (HP) nya.

Sekolah menerapkan peraturan tidak memperbolehkan para siswa nya untuk membawa handphone smartphone ke sekolah karena di khawatirkan akan mengganggu belajar para siswanya. Namun peraturan hanyalah peraturan tetap ada saja siswa yang melanggar aturan tersebut dengan berbagai macam alasan, salah satu alasannya yaitu karena para siswa kelas XII merasa sudah menjadi senior dan mempunyai keberanian, kepercayaan diri yang lebih untuk melanggar aturan tersebut.

Dengan adanya permasalahan tersebut Penulis bermaksud untuk mengupas lebih jauh tentang dampak dari penggunaan teknologi informasi dan kmunikasi khususnya handphone smartphone yang digunakan oleh para siswa di lingkungan sekolah dan pengaruhnya terhadap perilaku sosial siswa kepada guru maupun sesama siswa lainnya yang ada di lingkungan sekolah itu apakah dampak penggunaanya lebih ke arah positif atau negatif. Maka penulis akan melakukan penelitiannya yakni dengan judul "Dampak 


\section{Penggunaan Teknologi Informasi dan Komunikasi terhadap Perilaku Sosial Siswa di MAN 2 Kuningan”.}

\section{Rumusan Masalah}

Berdasarkan latar belakang dan identifikasi masalah dapat dirumuskan masalah penelitian sebagai berikut :

a. Bagaimana Penggunaan Teknologi informasi dan komunikasi siswa di MAN 2 Kuningan khususnya Handphone Smartphone ?

b. Bagaimana perilaku sosial siswa di MAN 2 Kuningan ?

c. Bagaimana dampak penggunaaan teknologi informasi dan komunikasi terhadap perilaku sosial siswa kelas XII di MAN 2 Kuningan?

\section{Tujuan Penelitian}

Adapun tujuan di dalam penelitian ini adalah :

a. Mengetahui penggunaan teknologi Informasi dan Komunikasi siswa di MAN 2 Kuningan.

b. Mendeskripsikan Perilaku Sosial siswa terhadap guru, siswa dengan siswa, di MAN 2 Kuningan.

c. Menganalisis dampak dari penggunaan teknologi informasi dan komunikasi terhadap perilaku sosial siswa di MAN 2 Kuningan.

\section{B. KAJIAN TEORI}

\section{Teknologi Informasi dan Komunikasi}

Teknologi informasi dan komunikasi ialah suatu alat bantu atau media yang di pergunakan sebagai sarana penyampaian pesan dari orang yang satu kepada orang lainnya sebagai bentuk interaksi secara langsung maupun tidak langsung, serta mempermudah manusia untuk berkomunkasi dari jarak jauh.

Dengan adanya perkembangan teknologi informasi dan komunikasi di dalam dunia pendidikan maka akan membantu dan mempermudah peserta didik dalam proses belajar. Peserta didik dapat dengan mudah mencari bahan-bahan materi pelajaran untuk belajar dimanapun dan kapanpun mereka mau tidak terbatas ruang dan waktu. 


\section{Handphone Smartphone}

Telepon genggam merupakan salah satu teknologi komunikasi yang bisa dikatakan sebagai media komunikasi interpersonal maupun media komunikasi kelompok. Menurut Bittner komunikasi interpersonal adalah penyampaian pesan oleh satu orang dan penerima pesan orang lain atau sekelompok kecil orang dengan berbagai dampaknya dan peluang untuk memberikan umpan balik dengan segera (Wiryanto, 2004: 32).

Handphone sebagai alat komunikasi informasi dari tahun ketahun mengalami perkembangan yang begitu pesat, yang awal kegunaannya hanya sekedar mengirim pesan melalui seluler sebagai pengganti surat dan untuk menelpon dari jarak jauh, kini kegunaannya lebih dari sekedar mengirim pesan dan telephone. Kemajuan handphone pada saat ini yang menyuguhkan begitu banyak media dan aplikasi yang terdapat di dalam handphone tersebut.

\section{Perilaku Sosial}

Pengertian Perilaku Sosial menurut Srijatun (2012:33) bahwa pengertian dari perilaku adalah "Cerminan kepribadian seseorang yang tampak dalam perbuatan dan interaksi terhadap orang lain dalam lingkungan sekitarnya'’.

Perilaku sosial pada anak usia dini ini diarahkan untuk pengembangan sosial yang baik, seperti kerja sama, tolong-menolong, berbagi simpati, empati dan saling membutuhkan satu sama lain. Untuk itu sasaran pengembangan perilaku sosial pada anak usia dini ini ialah untuk keterampilan berkomunikasi, keterampilan memiliki rasa senang dan periang, menjalin persahabatan, memiliki etika dan tatakrama yang baik. Dengan demikian, materi pembelajaran pengembangan sosial yang diterapkan di taman kanak-kanak, meliputi: disiplin, kerja sama, tolong-menolong, empati, dan tanggung jawab.

Pembentukan perilaku sosial yang tumbuh pada seseorang itu di pengaruhi oleh beberapa faktor diantaranya faktor kepribadian seseorang itu sendiri, faktor keluarga, faktor lingkungan tempat 
tinggal, maupun dari faktor budaya setempat. Karena dari faktorfaktor tersebut dapat mempengaruhi sikap dan perilaku seseorang dalam kehidupannya.

Berbagai bentuk dan jenis perilaku sosial seseorang pada dasarnya merupakan karakter atau ciri kepribadian yang dapat teramati ketika seseorang berinteraksi dengan orang lain. Seperti dalam kehidupan berkelompok, kecenderungan perilaku sosial seseorang yang menjadi anggota kelompok akan terlihat jelas diantara anggota kelompok yang lainnya.

Perilaku sosal dapat dilihat melalui sifat-sifat dan pola respon antar peribadi, sebagai berikut:

1) Kecenderungan Perilaku Peran

a) Sifat pemberani dan pengecut secara sosial

b) Sifat berkuasa dan sifat patuh

c) Sifat inisiatif secara sosial dan pasif

d) Sifat mandiri dan tergantung

2) Kecenderungan Perilaku dalam Hubungan Sosial

a) Dapat diterima atau ditolak oleh orang lain

b) Suka bergaul dan tidak suka bergaul

c) Sifat ramah dan tidak ramah

d) Simpatik atau tidak simpatik

3) Kecenderungan Perilaku Ekspresif

a) Sifat suka bersaing (tidak kooperatif) dan tidak suka bersaing (suka bekerja sama)

b) Sifat agresif dan tidak agresif

c) Sifat kalem atau tenang secara sosial

d) Sifat suka pamer atau menonjolkan diri

Dalam interaksi sosial itu dapat menimbulkan interaksi komunikasi. Karena di dalam ilmu sosial manusia tidak dapat hidup sendiri melainkan hidup berdampingan dari orang yang satu dengan orang yang lainnya, dengan adanya interaksi diantara orang yang satu dengan orang yang lainnya itu membutuhkan komunkasi sebagai 
penyampaian pesan dari satu orang ke orang lainnya, maka dari itu dalam berperilaku sosial terdapat interaksi komunikasi sebagai mempermudah bersosialisasi diantara orang yang satu denga yang lainnya.

\section{Dampak Penggunaan Teknologi}

Teknologi informasi dan komunikasi (TIK) sebagai bagaian dari ilmu pengetahuan dan teknologi secara umum adalah suatu teknologi yang berhubungan dengan pengambilan, pengumpulan. dalam bidang pendidikan, TIK banyak memiliki peranan. Teknologi informasi seakan telah menjadi pengalihfasihan buku, guru dan sistem pengajaran yang sebelumnya masih bersifat konvensional. (Sudradjat:2013)

1) Dampak Positif dari Teknologi Informasi dan Komunikasi dalam bidang pendidikan, antara lain:

a) Informasi yang dibutuhkan akan semakin cepat dan mudah di akses untuk kepentingan pendidikan.

b) Inovasi dalam pembelajaran semakin berkembang dengan adanya inovasi e-learning yang semakin memudahkan proses pendidikan.

c) Sistem administrasi pada sebuah lembaga pendidikan akan semakin mudah dan lancar karena penerapan sistem TIK.

d) Munculnya media massa, khususnya media elektronik sebagai sumber ilmu dan pusat pendidikan.

e) Munculnya metode-metode pembelajaran yang baru, yang memudahkan siswa dan guru dalam proses pembelajaran.

f) Sistem pembelajaran tidak harus melalui tatap muka.

g) Mengurangi ketertinggalan dalam pemanfaatan TIK dalam pendidikan dibandingkan dengan negara berkembang dan negara maju lainnya.

h) Peningkatan kualitas sumber daya manusia melalui pengembangan dan pendayagunaan teknologi informasi dan komunikasi.

2) Dampak Negatif dari Teknologi Informasi dan Komunikasi dalam bidang pendidikan, antara lain: 
a) Mempermudah terjadinya pelanggaran terhadap Hak Atas Kekayaan Intelektual (HAKI) karena semakin mudahnya orang dalam mengakses data, sehingga menyebabkan orang yang bersifat plagiatis akan melakukan kecurangan.

b) Mengakibatkan orang untuk berpikir pendek dan bertahan konsentrassi dalam waktu yang singkat, karena tergantung pada alat yang digunakan.

Adapun manfaat handphone untuk para siswa adalah :

a) Untuk mempermudah berkomunikasi

b) Untuk meningkatkan jalinan sosial

c) Untuk menambah pengetahuan tentang kemajuan teknologi

\section{METODOLOGI}

Penelitian menggunakan metode deskriptif kualitatif dengan teknik pengumpulan data menggunakan observasi, wawancara mendalam, dokumentasi, dan triangulasi. Teknik analisis data melalui tiga tahap yaitu reduksi data, penyajian data, dan verifikasi data. Sedangkan subjek penelitian adalah kepala sekolah, guru, dan beberapa siswa kelas XII IPS.

\section{HASIL DAN PEMBAHASAN}

1. Penggunaan teknologi informasi dan komunikasi siswa MAN 2 Kuningan sudah sangat baik jika untuk proses pembelajaran karena pihak sekolah sudah menyediakan fasilitas lab komputer serta Wi-fi untuk sarana yang dapat dipergunakan oleh para siswa nya.

MAN 2 Kuningan merupakan sekolah yang sudah maju karena dalam proses pelajaran sudah menggunakan alat teknologi informasi dan komunikasi yang memadai bagi para siswanya, dan MAN 2 Kuningan juga salah satu sekolah dalam pelaksaan ujian komputer yang menggunakan berbasis komputer dalam pelaksanaannya.

Namun teknologi informasi dan komunikasi handphone pihak sekolah tidak memperbolehkan siswanya untuk membawa handphone ke sekolah karena akan berdampak buruk untuk para siswa nya, jika siswa membawa 
handphone ke sekolah maka belajar mereka akan terganggu, fokus siswa akan terbagi antara materi pelajaran dengan handphone yang sedang dimainkan.

Berdasarkan hasil temuan penelitian menjelaskan bahwa penggunaan teknologi informasi dan komunikasi di MAN 2 Kuningan secara umum dari tahun ketahun adanya kemajuan dari fasilitas yang disediakan oleh pihak sekolah untuk para siswanya sudah sangat baik karena sekarang jumlah komputer yang ada di sekolah sudah bertambah dari tahun sebelumnya, penggunaan teknologi informasi dan komunikasi khususnya handphone yang peneliti temukan di dalam pengamatan bahwa meskipun sudah ada aturan tata tertib sekolah yang mestinya harus ditaati oleh para siswanya tapi ada saja siswa yang melanggar aturan tersebut, siswa yang memanfaatkan lengahnya pengawasan guru secara sembunyi-sembunyi berani membawa handphone ke sekolah bahkan berani mempergunakan handphone tersebut disaat jam pelajaran berlangsung, hal ini terjadi kemungkinan kurang ketatnya pengawasan dari para guru, dan kurangnya sanksi yang diberikan kepada siswa yang melanggar peraturan tersebut dan belum dapat member efek jera kepada siswa nya.

2. Sebagai makhluk sosial, seorang individu sejak lahir hingga sepanjang hayatnya senantiasa berhubungan dengan individu lainnya atau dengan kata lain melakukan relasi interpersonal. Dalam relasi interpersonal itu ditandai dengan berbagai aktivitas tertentu, baik aktivitas yang dihasilkan berdasarkan naluriah semata atau justru melalui proses pembelajaran tertentu. Berbagai aktivitas individu dalam relasi interpersonal ini biasa disebut perilaku sosial.

Perilaku sosial adalah kegiatan yang berhubungan dengan orang lain, kegiatan yang berkaitan dengan pihak lain yang memerlukan sosialisasi dalam hal bertingkah laku yang dapat diterima oleh orang lain, belajar memainkan peran sosial yang dapat diterima oleh orang lain, serta upaya mengembangkan sikap sosial yang layak diterima oleh orang lain.

Dari hasil wawancara dengan Bapak Hidayat sebagai Kepsek menjelaskan bahwa siswa MAN 2 Kuningan perilaku sosial hingga sampai saat ini 
masih menjaga nama baik sekolah dengan berperilaku sosial dengan baik, tidak pernah terdengar siswa MAN 2 Kuningan yang bermasalah dengan sekolah lain, dan untuk perilaku di lingkungan sekolah sejauh ini siswa MAN 2 Kuningan berperilaku sewajarnya tidak ada yang aneh-aneh, etika berbicara, sopan santun terhadap guru maupun dengan siswa lainnya baik. Adapun pelanggaran siswa yang membawa handphone ke sekolah tanpa sepengetahuan guru dengan alasan-alasan tertentu itu tidak dibenarkan dan biasanya siswa yang melanggar aturan tersebut itu berawal dari ikut-ikutan temannya.

Untuk menanggulangi dan mencegah munculnya perilaku menyimpang atau yang tidak diinginkan di kalangan siswa, maka perlu upaya pembinaan terhadap siswa secara terintegrasi antara sekolah dengan orang tua siswa, dan masyarakat. Sekolah juga mengharuskan untuk para siswanya harus senan tiasa bersikap 3S (senyum, sapa, salam) baik kepada guru maupun sesama teman, keharusan seperti ini juga diterapkan di semua organisasi yang ada di MAN 2 Kuningan, serta mendorong siswa untuk menyesuaikan perilaku berdasarkan nilai dan norma yang berlaku dalam masyarakat.

3. Dampak penggunaan teknologi informasi dan komunikasi khususnya handphone smartphone sadar tidak sadar pernah kita rasakan. Dampak penggunaan teknologi informasi dan komunikasi dapat dibagi menjadi dua yakni dampak postif dan dampak negatif. Positif atau negatif nya dampak yang terjadi dari penggunaan teknologi informasi dan komunikasi itu tergantung penggunaannya. jika orang yang dikuasai oleh teknologi besar kemungkinan akan berdampak negatif kepada pengguna teknologi tersebut, namun sebaliknya jika orang yang pandai memanfaatkan alat teknologi dengan baik dan bijak maka pengguna merasakan manfaat dari alat tersebut.

Dari hasil wawancara yang peneliti lakukan pada tanggal 17 Januari 2017 kepada ibu Inah salah satu guru yang mengajar di kelas XII IPS beliau mengatakan bahwa dampak penggunaan teknologi informasi dan komunikasi khususnya handphone itu sebenarnya tergantung kita yang 
menggunakannya, baik buruknya teknologi tersebut tergantung orang yang menggunakan alat tersebut.

Adapun hasil wawancara yang peneliti lakukan kepada salah satu siswa yang bernama Dadi kelas XII IPS 2 ia mengatakan bahwa dampak teknologi informasi dan komunikasi khususnya handphone semartphone dikalangan siswa banyak negatifnya karena ketika kita menggunakan handphone tersebut biasanya kita terlalu fokus dengan handphone yang sedang dimainkan, kita menjadi individualis, dan tidak mempedulikan lingkungan sekitar, jika handphone tersebut dipergunakan di saat jam pelajaran biasanya kita kurang fokus dengan materi yang sedang disampaikan oleh guru.

Dampak media (media effects) adalah perubahan kesadaran, sikap, emosi, atau tingkah laku yang merupakan hasil dari interaksi dengan media. Istilah tersebut sering digunakan untuk menjelaskan perubahan individu atau masyarakat yang disebabkan oleh terpaan media.

Perkembangan pemikiran dan teori tentang dampak media mempunyai sejarah alamiah karena dipengaruhi oleh setting waktu, tempat, faktor lingkungan, perubahan teknologi, peristiwa-peristiwa sejarah, kegiatan kelompok-kelompok penekan, para propagandis, kecenderungan opini publik, serta beragam penemuan-penemuan dan kecenderungan yang berkembang dalam kajian ilmu-ilmu sosial.

Dampak media juga dapat dibedakan ke dalam tingkatan individu, kelompok atau organisasi, institusi sosial, keseluruhan masyarakat, dan budaya (McQuail, 2000: 423). Lebih lanjut, McQuail (2000: 424) membedakan jenis-jenis perubahan yang dipengaruhi media adalah sebagai berikut: media menyebabkan perubahan yang disengaja, media dapat menyebabkan perubahan yang tidak disengaja, media dapat menyebabkan perubahan minor (bentuk atau intensitas), media dapat memfasilitasi perubahan (sengaja ataupun tidak), memperkuat yang sudah ada (tanpa perubahan), dan mencegah perubahan.

Menurut peneliti, melihat pernyataan beberapa narasumber dengan beberapa teori menyimpulkan bahwa hasil dari dampak penggunaan 
teknologi informasi dan komunikasi terhadap perilaku sosial siswa memang tidak begitu terjadi perubahan yang besar, perubahan kesadaran, sikap, emosi, atau tingkah laku yang merupakan hasil dari interaksi dengan media. Perubahan perilaku sosial siswa lebih berdampak kepada diri sendiri dan kepada siswa lainnya dibandingkan kepada guru. Perilaku siswa terhadap para guru masih baik tidak ada yang menyimpang, siswa tetap berlaku baik, bersikap sopan santun dengan para guru dan siswa yang membawa handphone smartphone ke sekolah lebih sering memepergunakan handphone smartphone nya di waktu istirahat dibanding waktu pelajaran, maka dari itu dampak penggunaan handphone smartphone terhadap perilaku sosial siswa lebih terasa dampaknya kepada siswa lainnya karena pada waktu istirahat interaksi siswa lebih banyak dengan siswa lainnya di banding dengan para guru. Dampak dari penggunaan handphone smartphone pada waktu istirahat tersebut maka interaksi diantara siswa yang satu dengan siswa lainnya menjadi terganggu, siswa yang memainkan handphone nya cenderung lebih fokus terhadap apa yang sedang mereka mainkan dan tidak memperdulikan lingkungan sekitarnya. Maka dari itu terjadilah perubahan perilaku sosial diantara siswa yang satu dengan siswa yang lainnya.

\section{E. KESIMPULAN DAN SARAN}

\section{Kesimpulan}

Berdasarkan hasil analisis penelitian dan pembahasan yang telah dikemukakan, maka dapat ditarik kesimpulan sebagai berikut:

a. Penggunaan teknologi informasi dan komunikasi di MAN 2 Kuningan sudah sangat baik, siswa menggunakan alat teknologi informasi dan komunikasi komputer, laptop dalam proses belajar di sekolah. Pihak sekolah pun memfasilitasi para siswa untuk belajar di sekolah dengan menyediakan sarana Lab Komputer dan dalam pelaksanaan ujian nasional di MAN 2 Kuningan sudah berbasis komputer. Sekolah melarang para siswa untuk membawa handphone smartphone dan mempergunakan handphone smartphone di lingkungan sekolah baik saat jam pelajaran 
maupun di luar jam pelajaran. Semua siswa kelas XII IPS 1, 2, 3 telah mempunyai teknologi informasi dan komunikasi handphone smartphone, para siswa kelas XII IPS membawa handphone ke sekolah tanpa sepengetahuan para guru.

b. Perilaku sosial siswa terhadap para guru masih sangat baik, siswa masih mengutamakan etika sopan santun dalam berperilaku maupun berbicara terhadap para guru karena di MAN 2 Kuningan untuk para siswa nya harus mengutamakan 3S yaitu: senyum, salam, sapa kepada siapapun yang ada di lingkungan sekolah. Namun interaksi sosial para siswa menjadi terganggu, terjadi perubahan perilaku sosial antara siswa yang satu dengan siswa yang lainnya ketika mereka sibuk menggunakan handphone smartphone di lingkungkan sekolahDampak dari penggunaan teknologi informasi dan komunikai handphone smartphone di lingkungan sekolah terbagi menjadi dua yaitu dampak positif dan dampak negatif. Dampak positif dari penggunaan handphone di lingkungan sekolah siswa mempergunakan handphone tersebut untuk mencari bahan materi tambahan, digunakan untuk berwirausaha dengan berjualan online melalui handphone smartphone.

c. Dampak negatif penggunaan handphone smartphone di lingkungan sekolah yaitu terjadi perubahan perilaku sosial siswa yang kurang baik, interaksi diantara siswa menjadi terganggu, siswa menjadi individualis, siswa tidak memperhatikan pelajaran, siswa tidak memperdulikan lingungan di sekitar mereka.

\section{Saran}

Berdasarkan kesimpulan hasil penelitian di atas, penulis menyampaikan beberapa saran sebagai masukan, yang diharapkan dapat bermanfaat bagi semua pihak. Adapun sarannya yaitu:

a. Bagi Guru

Perlu peningkatan dan penegakan hukum bagi para siswa yang melanggar peraturan sekolah, menambah sanksi hukuman yang edukatif bagi para siswa yang melanggar peraturan sekolah agar siswa mendapat efek jera untuk tidak mengulangi kesalahannya tapi disisi lain hukuman 
tersebut juga bermanfaat bagi siswa yang bersangkutan. Guru sebagai seseorang yang memegang peranan penting dalam proses belajar mengajar agar lebih kreatif lagi dalam cara penyampaian materi pelajaran agar siswa tidak merasa jenuh dan tidak ada kelengahan waktu untuk siswa melakukan hal lainnya di luar aktivitas pembelajaran.

b. Bagi Siswa

Hendaknya para siswa mematuhi peraturan yang ada di sekolah, mengikuti semua tata tertib yang berlaku di lingkungan sekolah agar terciptanya ke amanan, kenyamana. Dan para siswa juga harus pandaipandai mempergunakan handphone smarthphone sesuai manfaat kegunannya, dan dipergunakan sesuai waktu dan tempat yang tepat.

c. Bagi Peneliti

Perlu adanya penelitian lebih lanjut dan secara mendalam berkaitan dengan temuan penelitian ini tentang penggunaan teknologi informasi dan komunikasi handphone smartphone di lingkungan sekolah, sehingga dapat membantu pihak sekolah dalam meminimalisir dampak negatif dari penggunaan teknologi informasi dan komunikasi handphone smartphone terhadap perilaku sosisal siswa.

\section{DAFTAR PUSTAKA}

Anisa, Nurul. 2013. Penggunaaan Jejaring Sosial "Facebook" Terhadap Minat Belajar PAI Siswa Kelas VIII SMP Negeri 1 Yogyakarta. Skripsi, Fakultas Ilmu Tarbiyah dan Keguruan UIN Sunan Kalijaga Yogyakarta.

Arikunto. 2013. Prosedur Penelitian. Jakarta: Rineka Cipta.

Delphie, Bandi. 2009. Psikologi Perkembangan (Anak Berkebutuhan Kusus). Sleman: Intan Sejati Klaten.

Desmita. 2007. Psikologi Perkembangan. Bandung: Remaja Rosdakarya.

Effendy, Onong Uchjana. 2005. Ilmu Komunikasi Teori dan Komunikasi. Bandung: Remaja Rosdakarya.

Fadhilah, Ahmad. 2011. Pengaruh Penggunaan Alat Komunikasi Handphone (HP) Terhadap Aktivitas Belajar Siswa SMP Negeri 66 Jakarta Selatan. 
SkripsiFakultas Ilmu Tarbiyah dan Keguruan Universitas Islam Negeri Syarif Hidayatullah Jakarta.

Gunawan, Ary H. 2010. Sosiologi Pendidikan. (Cetakan ke-2). Jakarta: Rieneka Cipta.

Kartono, Kartini. 2007. Psikologi Anak (Psikologi Perkembangan). Bandung: Mandar Maju.

Mohamad, Monalisa. 2015. Dampak Penggunaan Alat Komunikasi Handphone Terhadap Aktivitas Belajar Siswa Kelas VII di SMP Negeri 12 Kota Gorontalo. Skripsi Jurusan Pendidikan Ekonomi Program Studi S1 Pendidikan Ekonomi Fakultas Ekonomi dan Bisnis Universitas Negeri Gorontalo.

Moleong, Lexy J. 2013. Metode Penelitian Kualitatif. Bandung: Remaja Rosdakarya.

Mulyana, Deddy. 2007. Ilmu Komunikasi. Bandung: Remaja Rosdakarya.

Mulyana, Arifin dan Cangara. 2011. Ilmu Komunikasi Sekarang dan Tantangan Masa Depan. Jakarta: Kencana Prenadamedia Group.

Mulyasa, E. 2002. Manajemen Berbasis Sekolah. Bandung : Remaja Rosdakarya.

Purwanto, Ngalim. 2004. Psikologi Pendidikan. Bandung: Remaja Rosdakarya.

Qamar, Syamsuwal. 2009. Internet Masuk Sekolah Desa. Bandung : Cipta Dea Pustaka.

Rangkuti, Ahmad Nizar. 2014. Metode Penelitian Pendidikan. Bandung: Citapustaka Media.

Setiadi, Julianto Arief dkk. 2009. Teknologi Informasi dan Komunikasi. Ristek: Jakarta.

Sugiyono, 2007. Metode Penelitian Kuantitatif, Kualitatif dan $R \& D$. Bandung: Alfabeta.

Syam, Nina W. 2012. Psikologi Sosial. Bandung: Simbiosa Rekatama Media.

Undang-Undang Republik Indonesia Nomor 11 Tahun 2008 Tentang Informasi dan Transaksi Elektronik: pkps. Bappenas.go.id.

Walgito, Bimo. 2002. Psikologi Sosial (Suatu Pengantar). Yogyakarta: Andi. 